\title{
Front Matter: Volume 11856
}

, "Front Matter: Volume 11856," Proc. SPIE 11856, Remote Sensing for Agriculture, Ecosystems, and Hydrology XXIII, 1185601 (12 October 2021); doi: $10.1117 / 12.2615051$

SPIE. Event: SPIE Remote Sensing, 2021, Online Only 


\section{PROCEEDINGS OF SPIE}

\section{Remote Sensing for Agric ulture, Ecosystems, and Hydrology XXIII}

Christopher M. U. Neale

Antonino Maltese

Editors

13-17 September 2021

Online Only, Spain

Sponsored by

SPIE

Cooperating Organisations

European Optical Soc iety

EARSeL-European Association of Remote Sensing Laboratories (Gemany)

ISPRS - Intemational Society for Photogrammetry and Remote Sensing

CENSIS (United King dom)

SEDOPTICA

INEUSTAR/INDUCIENCIA (Supporting Orga nisation)

Published by

SPIE

Volume 11856 
The papers in this volume were part of the technical conference cited on the cover and title page. Papers were selected and subject to review by the editors and conference program committee. Some conference presentations may not be available for publication. Additional papers and presentation recordings may be available online in the SPIE Digital Library at SPIEDigitalLibrary.org.

The papers reflect the work and thoughts of the authors and are published herein as submitted. The publisher is not responsible for the validity of the information or for any outcomes resulting from reliance thereon.

Please use the following format to cite material from these proceedings:

Author(s), "Title of Paper," in Remote Sensing for Agriculture, Ecosystems, and Hydrology XXIII, edited by Christopher M. Neale, Antonino Maltese, Proc. of SPIE 11856, Seven-digit Article CID Number (DD/MM/YYYY); (DOI URL).

ISSN: 0277-786X

ISSN: 1996-756X (electronic)

ISBN: 9781510645561

ISBN: 9781510645578 (electronic)

Published by

SPIE

P.O. Box 10, Bellingham, Washington 98227-0010 USA

Telephone +13606763290 (Pacific Time)

SPIE.org

Copyright @ 2021 Society of Photo-Optical Instrumentation Engineers (SPIE).

Copying of material in this book for internal or personal use, or for the internal or personal use of specific clients, beyond the fair use provisions granted by the U.S. Copyright Law is authorized by SPIE subject to payment of fees. To obtain permission to use and share articles in this volume, visit Copyright Clearance Center at copyright.com. Other copying for republication, resale, advertising or promotion, or any form of systematic or multiple reproduction of any material in this book is prohibited except with permission in writing from the publisher.

Printed in the United States of America by Curran Associates, Inc., under license from SPIE.

Publication of record for individual papers is online in the SPIE Digital Library.

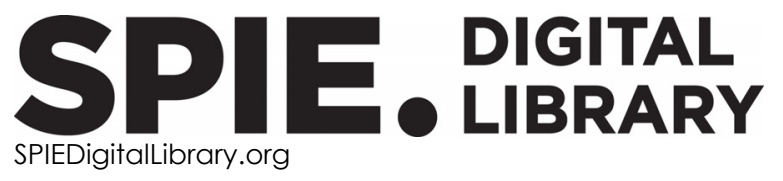

Paper Numbering: A unique citation identifier (CID) number is assigned to each article in the Proceedings of SPIE at the time of publication. Utilization of CIDs allows articles to be fully citable as soon as they are published online, and connects the same identifier to all online and print versions of the publication. SPIE uses a seven-digit CID article numbering system structured as follows:

- The first five digits correspond to the SPIE volume number.

- The last two digits indicate publication order within the volume using a Base 36 numbering system employing both numerals and letters. These two-number sets start with 00, 01, 02, 03, 04, 05, 06, 07, 08, 09, 0A, OB ... 0Z, followed by 10-1Z, 20-2Z, etc. The CID Number appears on each page of the manuscript. 


\section{Contents}

AGRICULTURE: BIG DATA AND POUCY

1185603 MORERA: latest Earth observation system to translate big data to agriculture [11856-1]

1185604 Supporting the common agric ultural policy with Sentinel-2 data and deep rec ument networks [11856-2]

MAPPING WTH SENTINE-2

1185606 Land cover mapping at national scale with Sentinel-2 and WUCAS: a case study in Portugal [11856-5]

1185607 A case of study of land surface phenology for CAP management using Sentinel-2 data to obtain phenometrics for winter cereals in Andalusia, Spain [11856-6]

1185608 Characterising the spring and autumn land surface phenology of Macaronesian species using Sentinel-2 data: the case of Canary Island [11856-7]

NITROGEN, CHLOROPHYL, AND CHG MONITORING

1185609 Estimation of chlorophyll content in radish leaves using hyperspectral remote sensing data and machine leaming algorithms [11856-8]

ADVANCES IN INIERPRETATION AND MAPPING

11856 OE Deep leaming for sub-pixel palm tree classification using spacebome Sentinel-2 imagery [11856-14]

11856 OF Google Earth Engine for land surface albedo estimation: comparison among different algonithms [11856-16]

11856 OG On the sensitivity of snow bidirectional reflectance to vaniations in grain characteristics [11856-17]

ENERGY BALANCE AND EVAPOTRANSPIRATION

$11856 \mathrm{OH}$ Comparative analysis of evapotranspiration using the SEBAL model and the evaporimeter pan method in the Huancane basin of Puno, Penu [11856-18] 
118560 ol Remote sensing and GIS based approaches to estimate evapotranspiration in the arid and semi-arid regions [11856-19]

11856 OK Development of GIS models via optical programming and python scripts to implement four empirical methods of reference and actual evapotranspiration (ETO, ETa) incorporating MODIS LST inputs [11856-21]

\section{VEGETATION MONITORING AND MAPPING}

$11856 \mathrm{OL} \quad$ Multi-sensor data acquisition for assessing the condition of vegetation [11856-23]

11856 OM Satellite imagery and climate variables suggest variations in the phenology of olive groves in Southem Spain [11856-24]

11856 ON Use of satellite remote sensing and climate data to predict the potential habitat distribution of Prosopis cineraria in the UAE [11856-25]

11856 OR Recumence techniques for the analysis of vegetation indices and climate anomalies: a study case in semiarid grasslands [11856-29]

YIED REIRIEVALAND WATER PRODUCTIVITY

11856 OS Estimation of olive groves cover crops net primary productivity using remote sensing data [11856-32]

\section{WATER MONITORING APPUCATIONS}

11856 OU Evaluating the effects of distinct water saturation states on the light penetration depths of sandtextured soils [11856-34]

11856 OV Improving water bodies detection from Sentinel-1 in South Africa using drainage and terrain data [11856-35]

11856 OW Coupling physically-based modeling and deep leaming forlong-term global freshwater availability monitoring and prediction [11856-36]

\section{UAV AND AIRBORNE SENSING}

$118560 \mathrm{X}$ Estimation of leaf area index at the late growth stage of crops using unmanned aerial vehicle hyperspectral images [11856-54]

11856 OY UAV-based scoring for iron chlorosis in soybean [11856-55] 
$11856 \mathrm{OZ}$ Application of UAV and spectrometric survey results to detemine agrochemical parameters of zonal soils used in agric ulture (East of European Russia) [11856-39]

$1185610 \quad$ Using radiative transfer models for mapping soil moisture content under grassland with UAS-bome hyperspectral data [11856-41]

CUMATE, DROUGHT, AND SOIL WATER CONIENT

1185611 Analysis of agronomic drought context based on satellite remote sensing over Westem Meditemanean region [11856-42]

1185612 ALOS-2 and Sentinel-1 use for retrieving soil moisture over cereal fields in semi-arid area: the Kairouan plain - central Tunisia [11856-43]

1185613 Root-zone soil moisture from process-based and remote sensing features in ANN [11856-44]

1185614 Detecting changes in vegetation and climate that serve as early waming signal on land degradation using remote sensing: a review [11856-45]

\section{POSTER SESSION}

1185615 Monitoring crop coefficient values with Sentinel-2 images to minimize imigation water losses [11856-22]

1185616 Estimation of holm oak flowening intensity in dehesa farms using high-resolution aenial images [11856-40]

1185619 Unauthorized landfills of solid household and industrial wastes detection in the Arctic and subarc tic temitories using remote sensing technologies [11856-49]

$118561 \mathrm{~A} \quad$ Spectral signature profiles of winter wheat in different growth stages under various environmental conditions [11856-51]

11856 1C Reflectance composites from multispectral satellite imageny for crop monitoring [11856-53] 
Proc. of SPIE Vol. 11856 1185601-6

Downloaded From: https://www.spiedigitallibrary.org/conference-proceedings-of-spie on 26 Apr 2023
Terms of Use: https://www.spiedigitallibrary.org/terms-of-use 